LAS IDEAS Y LAS INSTITUCIONES JURIDICAS

EN LA REPUBLICA DOMINICANA

FERNANDO PEREZ MEMEN

1.- Período colonial

La isla Española fue descubierta por Cristobal Colón el 5/XII/1492. Fue el primer territorio conquistado y colonizado por España en América, donde la Corona ensayó y experimentó los proyectos coloniales del Nuevo Mundo y estableció las primeras instituciones políticas, jurídicas, económicas y culturales.

En los primeros años la organización jurídica descansó en los Alcaldes Ordinarios o Mayores de las ciudades, que eran los jueces de Primera Instancia para los asuntos civiles y criminales. Como Juez de Apelación estaba el gobernador y por encima de éste el Real Consejo de Castilla. En 1511 se estableció la Real Audiencia, que sustituyó al Gobernador como Juez de Apelación. Con la creación del Real Consejo de Indias se sustituyó al Real Consejo de Castilla como tribunal de última instancia para los casos en que se recurría contra sentencias de la Audiencia (1). Había un caso cuando la Audiencia conocía en primera instancia; era el "Caso de Corte", cuando la Corona estaba involucrada como litigante. Las apelaciones pasaban al Real Consejo de Indias.

Al principio la Real Audiencia cubría toda América. Poco después perdió territorio con la creación de las de México (1527), Panamá (1536), Lima (1542) y Guatemala (1543). Sin embargo, su extensión fue amplia y así se mantuvo hasta el cierre del primer ciclo de dominio hispano (1795), pues comprendía el Caribe hispánico, parte de Centroamérica y de Suramérica (2).

A fin de frenar la corrupción administrativa, la Corona inició en la Española la Visita y la Residencia. La primera era una comisión administrativa para controlar y reformar la realización del orden institucional, sin suspender al funcionario respectivo. La segunda era un juicio que teóricamente se iniciaba al término del período del 
funcionario, o cuando el rey lo mandaba, y el juez asumía la jurisdicción del procesado cuya conducta se examinaba. Muchos juicios de residencia produjeron serios conflictos entre las autoridades así como tumultos (3).

La Española y las demás colonias estuvieron sometidas a las leyes de Castilla, principalmente Las Siete Partidas, que junto con otras fueron recopiladas y ampliadas en las Leyes del Toro de 1505. Desde muy temprano muchas leyes fueron dictadas para modificar las castellanas a causa de las nuevas circunstancias político-sociales que enfrentaban los colonizadores.

Los procedimientos de la Audiencia estuvieron regulados por la cédulas: la de 1511 y la de 1528. Cuando sus disposiciones fucron insuficientes se ordenó aplicar las de las Audiencias de Valladolid y de Granada. Toda parte tenía derecho al auxilio de un abogado. Cuando no tenía dinero para pagarlo el tribunal le ofrecía los servicios del Procurador de Pobres. Las Audiencias eran públicas, el proceso oral, las conclusiones escritas, asimismo las sentencias. En materia penal el procedimiento proveía la prisión preventiva, la libertad bajo palabra y bajo fianza, el embargo de los bienes del condenado y el indulto real. Además, al acusador se le premiaba con parte del dinero de la multa o de la venta pública de los bienes del condenado (4).

Los recursos en materia penal a las sentencias de la Audiencia se elevaban ante ella misma y se llamaban Revistas; las sentencias de éstas eran últimas y definitivas.

El 20 /VI/1776 la Corona creó el cargo de Regente de la Audiencia. Estaba por debajo del Gobernador y por encima de los Oidores. Velaba por el rápido e imparcial conocimiento de los recursos contra las decisiones del Gobernador. Debido a la extensión del contrabando se dispuso que uno de los Oidores fungiera como "Juez de Rescate".

Por la estrecha relación entre el Estado y la Iglesia sellada por el Regio Patronato Indiano, la justicia trascendía el orden temporal y penetraba en el religioso, por lo que las leyes de Indias castigaban. además de los delitos contra el Estado y los particulares los cometidos contra la religión (5). En Santo Domingo no hubo Tribunal de Fe, aunque sí un Comisario dependiente del de Cartagena de Indias y Tribunales Esclesiáticos que juzgaban a los clérigos que hubieren delinquido tanto en lo espiritual como en lo civil hasta el siglo XVIII, en que la Corona dispuso que en "los crímenes atroces" fueran juzgados por el juez 
esclesiático y el juez real (6).

En los delitos temporales la Iglesia prestó a la justicia secular su eficaz concurso. Así, usaba la excomunión y las censuras para presionar a los reos a confesar y a los testigos a declarar la verdad (7).

Las penas reflejaban las relaciones sociales dominantes en la estructura jurídica. A las Personas de "calidad" se les penaba con multa, confiscación de bienes, deportación etc. A las del estado llano, peninsulares y criollos, además de los referidos castigos, se les aplicaban el cepo, la corona, el remar en las galeras y la pena de muerte. A los esclavos y libertos: azotes, la marca con hierro candente, la mutilación de un miembro y el descuartizamiento del cadáver (8). Algunas de las penas hoy nos resultan risibles: al adúltero se le obligaba a mandar a buscar su mujer a España; a una mujer alborotadora a vivir pacíficamente; a otra acusada de prostitución a mudarse del barrio (9).

La justicia, reflejo de la estructura económica y social: latifundio, esclavitud, privilegios aristocráticos, economía casi de subsistencia..., mostraba la fea cara de la corrupción. Se acusaba a los Oidores de contrabandistas, de mantener relaciones maritales ilícitas y de lenidad y parcialidad en los juicios. Prueba de ésta última fue el caso de Juan Rincón, de familia adinerada, quien había delinquido varias veces, y era un ejemplar del criminal nato de Lombroso y no había sido penalizado debidamente. En los interrogatorios que se les hicieron por haber matado al padre Canales, a la pregunta de quien mató al sacerdote siempre respondía: "La justicia de Santo Domingo, Señor" (10).

\section{2.- Ocupación Francesa}

El fin de la primera dominación española se marcó con el Tratado de Basilea del 22/VII/1795, por el que España cedió a Francia la colonia de Santo Domingo, y la ocupación de ella por Toussaint L'Ouverture en 1801 y luego Leclerc en 1802.

Toussaint, líder de la independencia de Haití, abolió la esclavitud y sujetó a Santo Domingo español a la Constitución semiliberal de 1801. En el orden judicial estableció tribunales de Primera Instancia y Cortes de Apelaciones y una Corte de Casación que conocía sobre los recursos de nulidad contra las decisiones de las Cortes Apelación. Estableció, además, y esto es un rasgo totalitario de su 
régimen, tribunales extrajudiciale's para juzgar casos de alteración del orden público (11).

El régimen louverturiano concluvó en 18(1)2. Los franceses restablecieron la esclavitud y la trata negrera. Establecieron un régimen legal y judicial mixto acorde con el decreto de Napoleón del precitado año. A los franceses se le aplicaban las leyes metropolitanas (12), y a los hispanoamericanos las antiguas leyes españolas. Para éstos los asuntos de menor cuantía estuvieron bajo jurisdicción de los Alcaldes Municipales y para los franceses los Juzgados de Paz. Se creó un Tribunal de Primera Instancia mixto con un juez dominicano y dos franceses. Conocía en último recurso de las apelaciones contra las sentencias de los Alcaldes Municipales y los Jueces de Paz; como tribunal de primer grado conocía de los asuntos penales, reales o mixtos y aquellos en los que el Estado tuviera algún interés. El tribunal supremo era la Audiencia Imperial, dividida en dos secciones, una francesa y otra hispanodominicana. Estaba compuesto por seis Oidores, tres para juzgar a los hispanodominicanos bajo las antiguas leyes españolas y tres para juzgar a los franceses bajo sus propias leyes (13).

3.- Segundo período español (1809-1821) y primera independencia (1821-1822)

La Era de Francia concluyó en 1809 cuando Juan Sánchez Ramírez, apoyado por las milicias de Puerto Rico y una escuadra inglesa, se levantó en contra del régimen galo y devolvió a España la colonia de Santo Domingo, episodio que se denomina "La Reconquista de España". Sánchez Ramírez era un rico hacendado, con él triunfa el latifundismo como estructura económica y social, y el conservadorismo y el tradicionalismo como ideología. Su victoria fue la vuelta a la dominación colonial precisamente en los momentos en que se inicia la lucha emancipadora de varios países hispanoamericanos.

A este segundo período del régimen español se le llama "España Boba" y cubre los años de 1809 hasta el 1821. Se subdivide en 1809-12; 1812-14; 1814-20; y 1820-21. En el primero y en el tercero se restablecieron las antiguas leyes e instituciones y en el segundo y el cuarto estuvieron en vigencia las leyes e instituciones liberales de la Constitución de Cádiz. 
Conforme al texto gaditano se estableció un régimen judicial parą las provincias peninsulares y otro para las de ultramar. Para las primeras se creó un Tribunal Supremo, audiencias provinciales como Corte de Apelación, Jueces de Letras para las Primeras Instancias y alcaldes municipales para asuntos de menor cuantía o de simple policía. Las segundas no tenían recursos ante el Tribunal Supremo, las decisiones de las Audiencias en apelación sólo podrían ser objeto de un recurso de "nulidad" ante la más cercana. Los grados ordinarios en materia civil eran la Primera Instancia ante el Juez de Letras, la Apelación ante la Real Audiencia y el recurso de nulidad ante la Audiencia más próxima. En materia penal sólo hubo dos grados: la Primera Instancia ante el Juez de Letras y la apelación ante la Real Audiencia (14).

Un limitante del liberalismo del texto de Cádiz, en lo que se refiere a la división de los poderes, es que el rey -que tenía el Poder Ejecutivo- sería el que designaría a los jueces, con lo que se mantiene una vieja tradición propia del absolutismo monárquico.

El 9/X/1812 las Cortes dictaron una Ley de Organización Judicial para todo el reino, por la que se restructuró la justicia en Santo Domingo en el marco de la referida Carta Magna.

La España Boba concluyó en 1821 cuando el Lic. José Núñez de Cáceres, segundo hombre en el mando, dio un golpe incruento y emancipó al país de España. Fracasó en su intento de integrar el Estado Independiente de la Parte Española de Haití -como denominó a su proyecto político- a la Gran Colombia. Durante los dos meses y medio que duró su régimen mantuvo las Leyes de Indias y las instituciones políticas y judiciales hispanas.

\section{4.- El periodo haitiano (1822-1844)}

Juan Pedro Boyer unió Santo Domingo español a Haití el 9/II/1822. Abolió la esclavitud y sujetó el país a la Constitución de 1816. El sistema judicial tuvo sus bases en esa Carta Substantiva y en las Leyes de Organización de los Tribunales de 24/VIII/1808 y 15/V/1819.

Los códigos franceses se aplicaron en Haití desde 1816 hasta los años 1825-26, en que se promulgaron los haitianos, de suerte que cuando la parte dominicana se integró a Haití ya estaban en vigoror los códignos franceses y estos se empezaron a aplicar entre los dominicanos. En 1835 
se redactaron nuevos códigos: Penal, Procedimiento Civil y de Instrucción Criminal.

El aparato jurídico montado por los haitianos no se correspendía con la realidad social. La legislación francesa reflejaba los intereses de la burguesía, clase social inexistente en Haití, lo mismo que en Santo Domingo español; ambas eran sociedades precapitalistas, dedicadas casi a la agricultura de subsistencia. En Haití la clase alta la constituían algunos mulatos unidos a unos pocos comerciantes extranjeros, la mayoría de la población eran agricultores y soldados. En la parte del Este, en el vértice de la pirámide social, estaban los hateros latifundistas y por debajo una pequeña clase media y más abajo los soldados, artesanos y agricultores.

La realidad contradecía la teoría jurídica. Haití, en rigor, era una dictadura militar, sometida a la voluntad de Boyer. Tenía 40 mil hombres bajo las armas. El 70\% del presupuesto era para el ejército. Un viajero de aquel tiempo califica al gobierno haitiano como "una monarquía republicana sostenida por las bayonetas" (15). Y aseveraba: No poseyendo el Poder Judicial del país la reputación suficiente para asegurar que se respeten sus decisiones, la interpretación final de las leyes es siempre referida al Presidente personalmente, quien se convierte en juez..." (16).

Así, la democracia de las leyes no pasaba a la realidad social, la independencia de los poderes fue un mito y continuó la tradición jurídica de más de tres siglos, es decir, la secular falta de independencia de la justicia.

En relación con la materia penal, las disposiciones del Código Francés se adoptaron por el Código Penal haitiano. Las penas por casos de crímenes eran: la de muerte, trabajos forzados a perpetuidad o por cierto tiempo, la reclusión y la degradación cívica: La prisión perpetua conllevaba la muerte civil, por lo que el condenado perdía sus derechos de ciudadano. La mayoría de los crímenes políticos conllevaban penas de muerte. Y los delitos contra los particulares que llevaban esa penalidad eran: el asesinato, el parricidio, el infanticidio, el robo a mano armada y el incendio voluntario (17).

El Código de Instrucción Criminal haitiano estableció los jurados para los casos de crímenes. Eran doce y se escogían de listas preparadas por los Consejos de Notables de los Comunes. 
No había recurso posible contra el veredicto de un jurado. Una ley del 6/VIII/1841 estableció que ciertos crímenes, la mayoría de carácter político, serían conocidos por los tribunales sin asistencia del jurado (18).

5.- Periodo republicano: Primera República (1844-1861), Anexión a España (1861-1865) y Segunda República (1865-1916)

La dominación haitiana tocó su fin el 27/II/1844, cuando los dominicanos decidieron separarse de Haití y reasumir la soberanía, tal cual se expresa en lo que se ha llamado el Acta de Nuestra Independencia, a saber, el Manifiesto del 16/I/1884. En 1861 sucumbió la República y por tercera vez España dominó en Santo Domingo durante el período denominado de ia Anexión. Pero de nueva cuenta Santo Domingo postró su vocación por la libertad y sus interés en asumir su propio destino. Así, en 1865 se produjo la Restauración que duró hasta él 1916, cuando intervinieron los americanos.

La primera Constitución dominicana fue votada el 6/XI/1844. La misma tomó como modelos la de Filadelfia del 1787, las francesas de 1799 y 1804, la de Cádiz de 1812 y la haitiana de 1843.

Esa Carta Substantiva y la Ley de Organización de los Tribunales del 11/VI/1845 establecieron un sistema fruto de la combinación del español y el francohaitiano. Así, estaba compuesto de organismos de extracción francesa, como la conciliación obligatoria previa, los árbitros, las Cortes de Apelación y la Suprema Corte de Justicia y entremezclados con ellos estaban los Alcaldes Comunales, los Tribunales de Justicias Mayores y los Jueces de Residencia propios del régimen judicial hispano. Estas últimas instituciones fueron suprimidas en la Reforma Constitucional de 1854.

Entre otros aspectos conviene señalar: el Juicio por Jurados en materia criminal, la intervención del pueblo en la elección de los jueces, pues el Tribunado (así se llamó el principio a la Cámara de Diputados) escogía la terna de las listas presentadas por los Colegios Electorales y era de éstas de donde el Consejo Conservador (Cámara de Senadores) designaba los jueces y la autorización de la Suprema corte, previo examen, a los Defensores Públicos y a los Notarios a ejercer su profesión (19). 
El Art. 41 de la Constitución de 1844 estatuyó la división de los poderes del Estado; las demás Constituciones ratificaron este principio, pero en la práctica no se aplicó. La misma Carta Magna del 1844, en su Art. 210, legitimó la dictadura al concederle facultades extensas y sin responsabilidad alguna al Presidente de la República. Los demás textos constitucionales dieron tan amplias facultades al Poder Ejecutivo que hicieron dependientes del mismo a los otros poderes. La fuerza militar que siempre usí reflejó el dominio del sable sobre la toga.

"La justicia en nuestra ticrra, no obstante el empeño que se toman los hombres de buena voluntad en que sea verdad no es sino un mito". Así escribía en una carta del 1888 el dictador Heureaux quien, por razones de "conveniencia" política, intervenía en la justicia, de "modo que no se note su intervención ni los jueces se sientan lastimados" (20).

A causa de la estructura social que Hoetink califica de "Patronal", personas y grupos de interés y de expresión intervenían en la justicia, como por ejemplo la Iglesia y la Masonería; ésta última muchas veces lograba "devolver al hogar al prisionero" u obtener "perdón para el condenado" (21).

Interesa, también, señalar que sólo una pequeña parte de los crímenes llegaban a presentarse a la justicia. La organización policial era incompetente para investigar todos los crímenes cometidos sobre todo en el campo. Los campesinos no cooperaban por temor, de ahí que querían "estar bien con todos". Debido a la misma realidad social, el robo tanto al Estado como a la propiedad particular no era delito, según opinión de Eugenio María de Hostos (22).

Se dió el caso de la existencia de tribunales autónomos, como por ejemplo, en el Santo Cerro, provincia de La Vega, en la casa del Alcalde José Taveras, donde tenía cepos y cárceles para poner presos a hombres y mujeres, a los que aplicaba graves torturas para que confesaran (23).

La deficiencia de la justicia se debe atribuir también al bajo nivel educativo y a la carencia de formación jurídica en los propios agentes del Tercer Poder del Estado (24). Las República adoptó los Códigos franceses de la restauración, (25) leyes para una sociedad más avanzada, y con unas tradiciones y costumbres diferentes a las nuestras, su aplicación era difícil debido al bajo grado de desarrollo social. Asimismo pasó mucho tiempo sin que se tradujeran y adaptaran a nuestra realidad social. Muchos no entendían el francés, y muchos 
tribunales carecían de los Códigos, lo que imposibilitaba que los jueces motivaran y basaran sus sentencias. Además, durante casi medio siglo no había una institución académica donde se formara el abogado. Fue en 1880 cuando se fundó el Instituto Profesional que creó cátedras de Derecho; hasta entonces el entrenamiento de los estudiantes era por clases particulares seguidas por un examen ante la Suprema Corte de Justicia.

6.- Intervención americana (1916-24) y gobierno de Horacio Vásquez (1924-30)

El 24/XI/1916 los Estados Unidos ocuparon el país y lo sujetaron a un "gobierno militar". La inestabilidad y la anarquía política y el caos financiero, entre otras causas internas, se unieron a las externas, entre las cuales merecen destacarse, el temor de la administración Wilson a "la inexistente amenaza alemana en el Caribe" encarnada presuntamente en la República Dominicana en el caudillo Desiderio Arias. La intervención se inscribe en el marco de la Doctrina Monroe, el Destino Manifiesto y el Corolario Roosevelt, por el que los Estados Unidos impedirían hasta con la intervención militar la ocupación europea en América Latina (26).

Los americanos justificaron su intervención bajo el argumento de que Gobierno Dominicano había violado la Convención DominicoAmericana de 1907, por la cual los Estados Unidos asumirían el control de las aduanas -principal fuente de ingresos- a través de un Receptor General, quien tomaría el 55\% de los ingresos para el pago de la deuda pública (27) y a los empleados de esa oficina recaudadora; el restante $45 \%$ lo entregaría al Gobierno. Este no podía modificar las tarifas aduaneras ni ampliar la deuda sin el consentimiento del Presidente de los Estados Unidos, quien protegería al Receptor y sus auxiliares en caso de incapacidad de las autoridades dominicanas.

La ocupación duró 8 años. Los americanos destituyeron los ministros y en su lugar nombraron militares, suspendieron el Congreso, asimismo las elecciones, tomaron el control de las finanzas y las relaciones exteriores y establecieron, en rigor, un gobierno militar "sin responsabilidad que no fuese al Gobierno de los Estados Unidos" (28).

La administración de la justicia se mantuvo, sus empleados no 
fueron cancelados, pero en los casos en que estuvieran envueltos soldados americanos o "desprecio o desafío" al gobierno militar serían juzgados por tribunales militares llamados Prebostales (29).

El Gobernador militar asumió facultades ejecutivas y legislativas, asimismo judiciales, pues además de crear los referidos tribunales militares creó comisiones de reclamaciones con carácter de tribunales y el Tribunal de Tierras (30). "Gobernó -asevera Summer Welles- como autoridad suprema" (31).

Expidió una ley de censura, otra sobre sedición y otra prohibiendo la venta de bebidas alcohólicas a los soldados estadounidenses cuyas violaciones serían juzgadas por los tribunales prebostales, cuya jurisdicción fue ampliada "a casi todas las ofensas" contra el régimen militar (32).

Las Cortes cometieron abusos. Un ejemplo de ello fue el cometido contra Fabio Fiallo, gloria del Parnaso nacional, quien fue acusado de sedición por un escrito en el que criticaba la intervención. Fue condenado a tres años de prisión y una fuerte multa. (33)

Otros fueron torturados y matados sin ser juzgados (34), lo que motivó la protesta de la Iglesia Católica (35) y de los grupos nacionalistas, y que el Senado de los Estados Unidos abriera una investigación y enviará al senador Medill Mac Cormick, presidente del Comité Selecto, a obtener información. (36)

El gobierno expidió algunas leyes importantes que merecen señalarse: la que castiga el desfalco de los fondos públicos con el pago de una multa hasta tres veces la cantidad hurtada y de dos a cinco años de prisión; la relativa a causas por inconducta y faltas graves de los funcionarios judiciales; la de asistencia judicial; la que concede a la mujer el derecho a ejercer la abogacía; la ley de libertad bajo palabra; la que suprime la apelación en materia criminal; la que prohibe a los picapleitos de mala conducta representar a las partes en los tribunales; la que suprime la Cámara de Calificación y otorga al Juez de Instrucción la facultad de calificar los procesos de que conozca; la de drogas narcóticas; la que obliga a los testigos a comparecer por apremio corporal; la que reglamenta el cuidado de los menores condenados de acuerdo con los Arts. 66, 67 y 69 del Código Penal y la relativa a la rebaja de las penas criminales y correccionales (37).

Debido al Plan Hughes-Peynado (23/IX/1922) el Gobierno 
militar americano dió paso al Gobierno Provisionnal de Juan Bautista Vicini, quien reconocería las disposiciones tomadas por aquel, prepararía las elecciones y todo lo relativo al proceso de recuperación de la soberanía. Las tropas americanas continuarían en territorio dominicano hasta la asunción del mando del nuevo presidente.

Las elecciones fueron celebradas el 15/11I/1924. Las ganó el General Horacio Vásquez, candidato de la Alianza Nacional Progresista, a su contrincante Francisco. José Peynado, de la Coalición Patriótica de Ciudadanos.

El régimen militar dejó una importante infraestructura: las tres principales carreteras, la Ley de Registros de Tierras del 1920, que coronó las anteriores de Franquicias Agrícolas (1910) y de Partición de los Terrenos Comuneros (1911) que sirvieron de basé a la industria azucarera e hicieron de la economía del país una de plantación dependiente de los vaivenes de los precios mundiales del azúcar. Organizó la educación, la sanidad y la administración pública. Destruyó el antiguo ejército, creó la Policía Nacional y desarmó a la población. (38)

Con este soporte inició su marcha la administración Vásquez el 12/VII/1924. Pero hay que apuntar que en sentido económico la situación fue difícil. La crisis económica mundial que siguió al término de la Primera Guerra Mundial se reflejó con radicalidad en República Dominicana. Los precios del azúcar, café, tabaco y cacao se des̊plomaron. El propio Gobierno militar se entregó a los préstamos. Obtuvo casi siete millones para continuar las construcciones y pagar a los empleados. En 1924, Vásquez negoció una nueva convención que modificaba ligeramente la de 1907, por la que los Estados Unidos continuaban interviniendo en la vida financiera de la nación. En 1926 logró un préstamo de diez millone's para un vasto programa de obras públicas. Esto coincidió con el aumento de los precios de nuestros principales productos de exportación, antes señalados, que contribuyeron a una mejoría económica due llegó a su clímax en 1927.

Durante su régimen el país disfrutó de amplias libertades democráticas. Se dictaron varias leyes. En materia jurídica convendría señalar, entre otras, la que derogó definitivamente la pena de muerte, la de Notariado y la de Organización Jurídica (39) -aún vigente-, la de Colonización Fronteriza que abrió la posibilidad del establecimiente) de 
inmigrantes en las cercanías de la frontera, la de asistencia obligatoria a los hijos menores, fueran estos legítimos o naturales reconocidos, la que estableció por primera vez el sistema de Bien de Familia Inembargable, la que estableció sólo como válido el matrimonio civil (1924). Además, se restablecieron muchas disposiciones del Código de Procedimiento Criminal y del de Comercio que fueron modificados o abolidos por los americanos.

En 1924 el país sc afilió a la Sociedad de Naciones, establecida en 1920. Participó, entre otros eventos internacionales, en la sexta Conferencia Internacional americana celebrada en la Habana, Cuba, en 1927, donde se dictó el Código de Derecho Internacional Privado o Código Bustamante, el cual se ratificó en 1928. Se celebró, además, un Tratado fronterizo con Haití en 1929.

La gran depresión iniciada en 1929 se reflejó negativamente en la economía nacional, lo que llevó a una peligrosa crisis política que el presidente Vásquez contribuyó a acelerar. Su período debía concluir en 1928, pero lo prolongó hasta 1930 aduciendo que se juramentó por la Constitución de 1908 que estableció en 6 años el período presidencial. En 1930 quiso reelergirse y para ello modificó la Carta Fundamental, coyuntura que aprovechó el Movimiento Cívico del 23 de febrero del precitado año, que lo desalojó del poder y le abrió páso al jefe del Ejército, Rafael Trujillo Molina, quien dominó con manos ensangrentadas la escena nacional durante treinta y un años.

\section{7.- La era de Trujillo}

El 16/VIII/1930 asumió el poder Trujillo. Su ascenso al solio marcó el clímax de un proceso de frustraciones nacionales que se inicia desde la Primera República: inestabilidad política, regímenes dictatoriales, guerras civiles, intervenciones extranjeras y continuas crisis económicas.

Decía Maquiavelo que el Príncipe debe ser más temido que amado, y Montesquieu, en su Espíritu de las Leyes, observó que la base de la tiranía es el terror y el miedo. En ellos Trujillo basó su sistema. Ejerció un control absoluto sobre todo el país, era dueño de vida y haciendas. Frente a sus servidores mantuvo siempre un comportamiento dirigido por el interés. Valores como el afecto, la gratitud, el reconocimiento o la admiración no eran importantes en su vida personal y en su política (41). 
A varios de sus acólitos los elevó a las más altas posiciones, los dejó acumular grandes poderes y en el momento más inesperádo les retiró su favor y a algunos hasta los encarceló. Así sucedió con Rafael Vidal Torres, quien planeó el Movimiento Cívico del 23/II/1930, con Rafael Estrella Ureña, también artífice de aquel pronunciamiento, quien le acompañó como vicepresidente por un año (1930-31); con Daniel Henríquez Velázquez, uno de sus favoritos en los inicios de la "Era"; con su tío Teódulo Pina Chevalier, con Rafael Paíno Pichardo, con José María Bonetti Burgos, con Virgilio Alvarez Pina, con Anselmo Paulino y con el general José Estrella (42), comandante de las tropas que ocuparon la capital y desalojaron del poder a Vásquez, y su representante en el Cibao con poderes excepcionales para pacificar esa región (43).

Su principal instrumento de control fueron las Fuerzas Armadas. Fue pródigo en las dádivas a los militares, pero también constante en la desconfianza. Realizaba continuos cambios en las posiciones de mando. El régimen se basaba en la institución militar, pero ningún jefe aislado pudo soñar alguna vez en dominar a los institutos castrenses.

Hizo de las Fuerzas Armadas una de las más grandes y poderosas de América Central y el Caribe, y las convirtió en "un ejército de ocupación interna, en instrumento de la tiranía política... Era una fuerza policial" (44).

Su control se extendió a todo el país: sistema político, la prensa, la radio, los sindicatos, las logias masónicas, los clubes, las cámaras de comercio, las asociaciones profesionales... en suma en todo grupo que pudiese presionar o influir en la vida nacional. Desde muy temprano neutralizó y debilitó a la oposición. Durante su campaña de 1930 logró liberarse de la mayoría de sus adversarios." Algunos fueron encontrados acribillados a balazos; otros, con más suerte, escaparon al exilio" (45).

Sometió al pueblo a su voluntad despótica y tiránica. Obtuvo la sumisión del país. "Lo grave -escribió Galíndez- no son las detenciones ilegales, ni siquiera los asesinatos: lo grave es la destrucción total del espíritu de un pueblo..." Esto lo logró por el terror sistematizado, que se intensificó en los últimos tiempos de su régimen, por la adoctrinación de la juventud en las escuelas, por una prensa adulona y servil, por el espionaje constante, y lo logró, sobre todo, "con la humillación constante de las personas más representativas; es rarísima la personalidad dominicana que no ha colaborado con el régimen" (46). 
El dictador, también, tuvo en sus manos la economía del país. Fue el mayor propietario de ingenios azucareros; asimismo de las tierras y el ganado. La mayor parte de las empresas industriales, comerciales y financieras eran de él. Se puede decir que el país fue su gran empresa y él su principal empresario. Se convirtió en uno de los hombres más ricos del mundo. Cuando murió se calculó su fortuna en 800 millones de dólares.

Durante su régimen la división de los poderes fue una farsa, una descarada burla. Sometió el Poder Legislativo a su voluntad. Senadores y Diputados eran designados por él y avalados por la farsa electoral a la que concurría su partido, sin oposición alguna, pues era el único existente. Al nombrar o elegir a un congresista le obligaba a firmar una carta de renuncia sin fecha, de esta manera le removía a su voluntad fingiendo que renunciaba el incumbente (47).

El Poder Judicial estuvo al servicio de su tiranía, como expresa una de sus principales víctimas, el Dr. Juan Isidro Jimenes Grullón, notable intelectual y político fenecido (48).

El dictador de manera formal mantuvo una estructura política de carácter democrática. Se proclamó, asimismo, campeón de la democracia en nuestro país y en América. La Constitución del 1947, en el Art. 6, Tit. II, garantizaba los derechos individuales, así también los textos de 1955, 1959, 1960 (28/VII) y (2/XII); sin embargo, la práctica política lo contradecía cotidianamente. Todo el mundo estaba expuesto a ser apresado por la policía sin orden judicial alguna, y esa detención se prolongaba indefinidamente. En algunos casos el apresamiento era de corta duración, particularmente en casos de sospechas; en otros terminaba en un juicio que legalizaba lo sucedido, y en otros se mataba al detenido antes de ser procesado.

No sólo opositores, sino también personas que ocuparon posiciones preeminentes sufrieron esas experiencias. Como el presidente del Senado Manuel de Jesús Troncoso de la Concha, detenido en 1930; como el expresidente de la misma Cámara Mario Fermín Cabral, uno de los cabecillas del Movimiento Cívico que llevó a Trujillo al poder, detenido en 1941; como el director de El Caribe, Germán Ornes Coiscou, preso en 1945. Muchas personas a los pocos días de estar encarceladas se rindieron incondicionalmente al régimen y de la cárcel pasaron a ocupar altos cargos oficiales; uno de ellos fue el sobrino del Presidente Vásquez, a quien Trujillo le dió el golpe de Estado, Máximo Vásquez Gautier (49). 
En un discurso pronunciado el 9/I/1933 ante la Asamblea de Magistrados, Trujillo de manera hipócrita e insidiosa proclamó: "Sois independientes y sois responsables. Nada ni nadie os debe influir, por vuestra dignidad y vuestra responsabilidad porque cualquier servicio a extraños intereses o ajenas pasiones os conduce a pecados censurables, de apostasía, de prevaricación o abuso de poder, que son a mi juicio las más groseras formas de traición social..." Y subrayó: "Os siento independientes de mi, delante de mi y al lado mío..." (50).

Esta idea fue permanente en todos sus discursos y mensajes relativos al Poder Judicial (51). Pero la Justicia fue un instrumento que utilizó para humillar a sus validos, castigar a sus opositores y para mostrar la eficacia de su sistema, en términos de controlar y reducir la criminalidad. Para ello se valió del Ejército, que junto con la Policía Nacional perseguía a los delincuentes y opositores.

La penalidad fue rigurosa; ya hemos visto el caso de los opositores. Para los delincuentes comunes era rígida. Por delitos de simple policía, como el robo de un radio, el manejar ebrio, asimismo por exceso de velocidad, por vagancia -que era un delito, como lo fue en tiempo de Toussaint (1801-02) y de Boyer (1822-43), se castigaba con una semana a un mes de prisión y multa de 50 a 100 pesos (52). El peculado lo castigaba con severidad. Por una pequeña suma robada al erario se condenaba hasta un año de prisión (53).

Muchos ladrones eran salvajemente torturados, y a muchos se les mataba aplicándoles la Ley de Fuga, como sucedió con los asaltantes del Royal Bank of Canada, sucursal de Santiago, cuyo robo fue el más grande y osado que se cometió durante la Era de Trujillo (54). El hecho ocurrió el 6/XI/1954. Trujillo lanzó el Ejército contra ellos. Al día siguiente fueron capturados y pocos días después fueron matados. El dictador aprovechó el hecho para mostrar la rapidez y eficacia de la Justicia bajo su régimen. El presidente del Banco envió una carta de gratitud a Trujillo (55).

La Feria internacional de la Paz organizada en 1955 para celebrar los 25 años de la "Era", dió la impresión de estabilidad del régimen. Pero al mismo tiempo se gastaban fuerzas que finalmente lo destruirían. Las condiciones sociales y políticas en América Latina contrariaban a las dictaduras y favorecían a los gobiernos democráticos. En Argentina Perón era derrocado (19/XI/1955); asimismo Julio Lozano Díaz, de 
Honduras (21/X/1956); Gustavo Rojas Pinilla, en Colombia (10/V /1957); Marcos Pérez Jiménez, en Venezuela (enero 1958); Fulgencio Batista, en Cuba (1/I/1959). A lo que se suma la tendencia cada vez más acentuada de los Estados Unidos a retirar su apoyo al gobierno de Trujillo. Así, no dieron permiso para la venta de armas y municiones, y retiraron su misión de la Fuerza Aérea. La administración Eisenhower percibió al régimen trujillista como "un estorbo, una incómoda herencia de épocas pasadas, que duraba ya demasiado y que ponía en peligro el futuro y preparaba, sin saberlo, el camino del castrismo" (56).

Pocas semanas después del triunfo de Castro asumía el poder en Venezuela Rómulo Betancourt, que había revelado hostilidad hacia Trujillo y apoyó a los exiliados entre 1945 y 1948. A estos hechos se agregan la invasión del 14/VI/1959 de un grupo de jóvenes exiliados con ayuda de Fidel y respaldo moral de Betancourt, a quien Trujillo mandó a matar en 1960; la condena de la OEA al régimen en la Sexta Reunión de Consulta de Ministros de Asuntos Exteriores, celebrada en San José, de Costa Rica, en agosto de aquel año, por la que todos los Estados Miembros suspendían las relaciones diplomáticas y económicas con la República Dominicana; la Conspiración del Movimiento Clandestino 14 de Junio y la ruptura de la Iglesia Católica con Trujillo, a causa de la Pastoral del 25/I61960 que condenó la violación de los derechos humanos por la dictadura.

Todas estas causas internas y externas se conjugaron y conformaron el fenómeno de la caída del dictador. La noche del 30/V/1961 fue ajusticiado por un grupo de hombres, en una acción heroica que selló el fin de la horrorosa dictadura.

\section{8.- Transición de la dictadura a la democracia (1961-1988)}

La muerte de Trujillo abrió las compuertas que permitió la salida a las energías y las ansias libertarias de la nación. Las mismas se estrellaban violentamente contra la estructura política trujillista, que el hijo del dictador, Ramfis, y sus servidores, se empecinaban en mantener vigente.

El Dr. Joaquín Balaguer pretendió convencer a Ramfis de la necesidad de dar una apertura democrática, pero la presión interna era vigorosa, asimismo la internacional, las que favorecían la salida de los 
Trujillo y el establecimiento de un régimen democrático. De suerte que las condicionés políticas de aquella época llevaban a la ineluctable e irreversible destrucción de la maquinaria trujillista y de la salida de los Trujillo.

Ramfis se vió forzado a renunciar el 14/XI/1961. El 17 abandonó la República Dominicana. El 19 un golpe de Estado por el comandante de la base aérea de Santiago, Pedro Rafael Rodríguez Echavarría, impidió que "los tíos malvados", Héctor y José Arismendy Trujillo (Petán), reeditaran la tiranía. Antes de partir, Ramfis mató sádicamente a los seis prisioneros sobrevivientes del asesinato de su padre (57). "Así terminó -dice Martín- el baño de sangre con el que había nacido y terminado el régimen de Trujillo" (58).

Fuera del país los Trujillo, la presión popular dirigida particularmente por la Unión Cívica Nacional, lidereada por el Dr. Viriato A. Fiallo, prominente luchador antitrujillista, quien permaneció en el país durante la "Era". y nunca sirvió al régimen, y el Movimiento 14 de Junio, orientado por el Dr. Manuel Tavarez Justo, joven luchador antitrujillista, presionaron al Dr. Balaguer, con una huelga que duró 12 días -la más larga en la historia política dominicana- y "una de las manifestaciones populares más impresionantes en la historia reciente de América Latina" (59). Se logró un acuerdo bajo la mediación de John Galvin Hill y Arturo Morales Carrión, en representación de los Estados Unidos: El Congreso sería disuelto, los Poderes Legislativo y Ejecutivo estarían en mano de un Congreso de Estado de siete miembros, presidido por Balaguer.

Este acuerdo fue de corta duración. El año de 1962 se inició con una impresionante dinámica del proceso político: renuncia y salida del país del Dr. Balaguer, golpe de Estado de Rodríguez Echavarría, apresamiento de los Consejeros de Estados -excepto Imbert y Amiama Tió- establecimiento de la Junta Militar, golpe contra ella, apresamiento de Rodríguez Echavarría y reestablecimiento del Consejo, presidido ahora por el Dr. Rafael. F. Bonnelly, que antes había sido su Vicepresidente.

Cuando el Consejo reinició su marcha la República padecía gravísimos problemas económicos y sociales. El país era agrícola. De una población de 3 . millones de habitantes, el $70 \%$ era rural. La agricultura era atrasada. La estructura agraria era -como todavía lo es 
hoy- latifundista y minifundista. Entre el 195()-60) el áréa total cultivada sólo había aumentado en un $13 \%$, mientras el número de predios agrícolas creció en un $62 \%$. Un alto porcentaje era analfabeto. Las condiciones de salud eran deprimentes. "Casi dos millones de personas vivían en condiciones subhumanas" (60)).

La inestabilidad política que sufrió el país desde la muerte de Trujillo hasta la instalación del segundo Consejo de Estado (18/1/1962) afectó seriamente a la economía. En 1961 las exportaciones bajaron un $6 \%$. El desempleo se estimó entre el 33 y el $56 \%$.

Los problemas de la Justicia eran graves. La tiranía había hecho perder la fe en ella. El Consejo de Estado procuró levantarla: "la justicia -expresó el Procurador General de la república el 26/1/1962- sabrá ganar la confianza "tan necesaria para mantener el ordenamiento jurídico de la nación". El Consejo, que tenía funciones ejecutivas y legislativas por la Constitución de 29/XII/1961, expidió el 5/I/1962 la Ley 5785 que confiscó los bienes de Trujillọ y sus afines. En mayo de ese año créó el Tribunal de Confiscación de Bienes, que tenía atribuciones penales y civiles. Fue suprimido por el Triunvirato el 6/VI/1964 (61).

El Consejo creó, además, la Cámara Penal con jurisdicción en toda la República para enjuiciar a los que amparados por la tiranía cometieron crímenes contra el pueblo. El 25/XI/1962 ese Tribunal condenó a penas de 30, 20, 5 y 3 años de trabajos públicos a los asesinos de las Hermanas Mirabal: Patria, Minerva y María Teresa, y a su chofer Rufino de la Cruz -horrendo crimen cometido al final de la tiranía, que consternó e hizo crecer el odio del pueblo contra el tirano (62).

En el ocaso de la gestión del gobierno colegiado, la magnitud de los problemas de la Justicia era reconocida y preocupaba a las autoridades. El Procurador General de la República, Antonio García Vásquez, en declaraciones al periódico El Caribe del 14/II/1963, declaraba su interés en acelerar las labores judiciales, en crear un Juzgado de Instrucción y en aumentar el personal ayudante de las Cámaras Penales.

El Consejo de Estado concluyó su gestión el 27/II/1963. Le sucedió el Profesor Juan Bosch, destacado intelectual y político, fundador en el exilio del Partido Revolucionario Dominicano. Ganó las primeras elecciones libres después de 31 años de dictadura el 21/XII/1962 por $58.1 \%$, su más cercano contendiente fue el Dr. Viriato A. Fiallo, con el 
30.1\%; presidente de la Unión Cívica Nacional (63).

El 29/IV/1963 la Asamblea Revisora votó la Carta Substantiva más liberal de la historia constitucional dominicana. El texto parece inspirarse en las constituciones de algunos países de Europa y en la mexicana de 1917. Entre otros aspectos, estatuye la herencia del hijo natural, la supervisión de la educación por el Estado, la condena al latifundio y al minifundio, el derecho del campesino de ser dotado de tierras, prohibición del desahucio y desalojo contra los labradores que explotan por un contrato o por ocupación de un año, la protección del Estado al matrimonio, a la familia, a la maternidad, al niño y la plena capacidad civil de la mujer dominicana.

El Art. 135 declaraba que se votaría una ley que establecería la carrera judicial. El gobierno, además, manifestó el interés en la recta administración de la Justicia, y en resolver, entre otros problemas, la falta de personal, que impedía el funcionamiento de algunos tribunales, como expresó el Ministro del ramo, Luis Lembert Peguero, al periódico El Caribe 5/III/1963.

El gobierno de Bosch sólo duró siete meses. El 25/XI/1963 un golpe de Estado culminó abruptamente el proceso de agonía que desde su instalación padeció. Fue sometido a fuertes críticas y presiones por parte de la oposición y hasta de su propio partido.

En su lugar gobernó el Triunvirato del 26/IX/1963 hasta el 24/IV/1965. Expidió, entre otras medidas judiciales, una nueva Ley de Confiscaciones, en cuya virtud cualquier acción o impugnación por ante el Tribunal de Confiscaciones se "declara nula y sin ningún efecto" (64). Más tarde, como antes se señaló, y ahora se reitera, abolió el preindicado Tribunal. En 1964 suprimió la Secretaría de Justicia y sus atribuciones la pasó al Procurador General de la República.

El 24/IV/1965 se produjo un levantamiento contra el Triunvirato. Los militares se dividieron en dos grupos; uno que abogaba por el restablecimiento de la Constitución del 1963 y del Gobierno de Bosch y el otro por la creación Junta Cívico-Militar que convocara a las elecciones para el establecimiento de un nuevo gobierno constitucional. En esta circunstancia surgió la intervención americana del referido año. Después de varios meses de lucha entre el gobierno del Coronel Francisco A. Caamaño Deñó y el del General Imbert Barreras, apoyado por los americanos, se logró un acuerdo de paz y el establecimiento de un 
gobierno provisional, encabezado por Héctor García Godoy, legitimado por el Año Institucional del 3/IX/1965.

Gobernó hasta el 1/VII/1966, cuando ocupó la primera magistratura el Dr. Balaguer. De esa fecha hasta hoy han transcurrido 22 años. Ha sido el período más largo en la historia política dominicana en que se ha vivido de manera estable. La democracia ha dado muestras de consolidación. En el año 1978 entregó el mando a Antonio Guzmán Fernández, candidato del Partido Revolucionario Dominicano, quien ganó las elecciones de ese año. En 1982, otro candidato del precitado partido, el Dr. Salvador Jorge Blanco, triunfó en el torneo electoral contra Balaguer. Recibió el poder de manos del Lic. Jacobo Majluta, sustituto del fenecido presidente Guzmán. En la nueva consulta eleccionaria del 1986, el Dr. Balaguer, de nueva cuenta, ascendió al solio presidencial. Como se puede observar la transmisión del mando se ha realizado de manera normal y pacífica.

También se revelan en los últimos años progresos en el respeto de los derechos humanos, en la preocupación e interés por fortalecer las instituciones, en la obediencia a la ley y en la organización y administración de la justicia con eticidad. Hoy por hoy es un tema palpitante. Así se habla de sanear a la Justicia, de hacer un poder plenamente independiente, que sea un freno a los abusos del poder político y castigue severamente al peculado. Se piensa que si ella cumple el papel ético-social a que está llamada, la democracia será fuerte y perdurable. En ese tenor, la Iglesia Católica, a través de la Pastoral de sus obispos del 24 de enero del año en curso expresó: "Inquieta a todos que el Poder Judicial vuelve a resentirse en su credibilidad. Tiene que ser y aparecer diáfanamente imparcial y veraz"... Y el Presidente de la República, en su mensaje de la asamblea Nacional el 27 de febrero siguiente, con voz admonitoria exclamó: "Ojalá que aquí, tarde o temprano, no tengamos también que decir encarándonos a los miembros de nuestra judicatura que fue la justicia la que dictó la sentencia condenando a la pena capital la democracia dominicana" (65). 
1.- VEGA, Wenceslao.- Historia del Derecho Colonial Dominicano. Colección Ensayo, Premio Siboney. Santo Domingo, R. D. Editora Taller, 1979. P. 48; y del mismo autor Historia del Derecho Dominicano. Instituto Tecnológico de Santo Domingo, Sto. Dgo. R. D., Editora Amigo del Hogar. 1986. Págs. 35 y 36.

2.- Véase MALAGON BARCELO, Javier.- El Distrito de la Real Audiencia de Santo Domingo, Ciudad Trujillo, R. D., Universidad de Santo Domingo, 1942.

3.- $\quad$ PEREZ MEMEN, Fernando.- Estudios de Historias de las Ideas en Santo Domingo y en América. Santo Domingo, R. D. Academia de Ciencias de la República Dominicana, 1987. PP. 113-121.

4.- VEGA ... Historia del Derecho Dominicano... 51 y 52.

5.- Véase PEREZ MEMEN, Fernando.- La Iglesia y el Estado en Santo Domingo (1700-1853), Santo Domingo, R. D., Universidad Autónoma de Santo Domingo, 1984.

6.- IBID.

7.- VEGA ... Historia del Derecho Dominicano. Nota 31, p. 53.

8.- $\quad$ IBID.

9.- La Vida Escandalosa en Santo Domingo en los siglos XVII y XVIII, documentos editados por Frank Moya Pons. Santiago, UCMM, 1974, Págs. 64, 82 y 118; Cfr VEGA... Historia del derecho dominicano... 53.

10.- PEREZ MEMEN... La Iglesia y el Estado... 82-84. 
11.- ARDOUIN, B.- Etudes sur L'Histoire d'Haiti. Puerto Príncipe, 1853. Reedición del 1958. IV. 76; Cfr VEGA... Historia del Derecho Dominicano... 106.

12.- Las leyes francesas aplicadas fueron las del período intermedio entre las de la monarquía y las de Napoleón. VEGA... Historia del Derecho Dominicano... Nota 169, p. 107.

13.- RODRIGUEZ DEMORIZI, Emilio.- La Era de Francia en Santo Domingo. Ciudad Trujillo, R. D., El Caribe 1955. P. 241 ss; Vega. Ob. Cit., 107. En ese período en Francia se promulgaron los Códigos Napoleónicos: El Civil (1804); Procedimiento Civil (1806); Comercio (1807) e Instrucción Criminal (1810).

14.- Vega, Ob. Cit. 115.

15.- BROWN, J.- History and Present Condition of Santo Domingo. Philadelphia, 1837. T. II, p. 258; Cfr Vega, Ob. Cit., 137.

16.- IBID.

17.- IBIDEM, 151.

18.- IBID.

19.- IBIDEM, 203, 204 y 214; Avelino, Francisco Antonio.- Instituciones Jurídicas y Políticas en el Nacimiento de la Primera República. En La Sociedad Dominicana Durante la Primera República (1844-1861). Tirso Mejía Ricart (editor). Sto. Dgo., R. D. Editora UASD y Alfa y Omega, 1977. P. 131.

20.- Archivo General de la Nación (AGN). Cartas al Presidente Heureaux. 5/IV/1888; Cfr Hoetink, H.- El Pueblo Dominicano (18501900) Apuntes para su Sociología Histórica. Segunda edición. Santiago, R. D., Universidad Católica Madre y Maestra, 1972, Págs. 182 y 183. 
21.- DESCHAMPS, Enrique.- La República Dominicana, directorio y guía general. Santiago, R. D., 1906. P. 197; Cfr Hoetink. Ob. Cit., 185.

22.- RODRIGUEZ DEMORIZI, Emilio.- Hostos en Santo Domingo. C. T., R. D., Imp. J. R. Vda. García Sucs. 1939. Vol. I. 287; Cfr Hoetink, Ob. Cit., 185 y 196.

23.- El Eco del Pueblo, 24/VI/1889; Cfr Hoetink, Ob. Cit. 184.

24.- La profesión jurídica muestra su progresión desde el 1924 hasta nuestros días. En 1883 una sola persona se graduó en el Instituto Profesional de Lic. en Derecho y era extranjera. En varios años no hubo titulados (1889, 1892, 1894, 1895, 1897 y 1905). En 1924 se graduaron 15 y en 1967, 205 en la Universidad Autónoma de Santo Domingo.

25.- Después de muchos años, finalmente, se tradujeron y sancionaron los Códigos: Civil (16/IV/1884); Procedimiento Civil (17/IV/1884); Instrucción Criminal (24/VI/1884). La institución del Ministerio Público la reglamenta el Código de Instrucción Criminal. Pero muchos años antes varias leyes la normaban: Ley Orgánica de los Tribunales (1855); Reglamento Orgánico Judicial (1866) y las de 1873, 1874, 1874 y 1884 y posteriormente la Ley de Organización Judicial de 1927, hoy en vigencia. Constitucionalmente las funciones del Ministerio Público las estatuyen los textos constitucionales desde el primero de 1844 hasta el vigente de 1966. Precisamente la Ley 485 del 1964 concedió al Procurador General de la República las atribuciones que antes tenía el Secretario de Justicia.

26.- GLEIJESES, Piero.- La crisis Dominicana. Fondo de Cultura Económica, México, 1984. p. 30 y 339. Nota 60; PEREZ MEMEN, Fernando.- Contexto Internacional de la Historia Dominicana. En la Sociedad Dominicana Durante la Segunda República (1865-1924) Tirso Mejía Ricart (editor). Editora de la Universidad Autónoma de Santo Domingo. Santo Domingo, R. D., 1982. Págs. 244 y 245.

27.- En 1905 era de 40 millones de dólares. Jacob Hollander, experto financiero enviado por Roosevelt, estimó que podría reducirse, en 
términos legales, a la mitad. En 1906 con la presión de los EE. UU se redujo a 17 millones de dólares. Para lo relativo a la deuda dominicana Véase HERRERA, César.- De Harmont a Trujillo. Impresora Dominicana, Ciudad Trujillo, R. D., 1953; y del mismo autor Las Finanzas de la República Dominicana Vol. I. Impresora Dominicana, Ciudad Trujillo, R. D. 1955.

28.- WELLES, Summer.- La Viña de Nabot. Prólogo y traducción de Manfredo Moore. Ediciones Taller, Santo Domingo, R. D., 1973. Vol. 2. P. 259; VEGA, Historia del Derecho Dominicano... 342.

29.- WElles, OP. CiT., Proclama del Capitán H. S. Knapp. Santo Domingo, R. D.., 29/XI/1916, Vol. 2, Págs. 252-255; KNIGHT, Melvin M. Los Americanos en Santo Domingo. Imprenta Listín Diario. Publicaciones de la Universidad de Santo Domingo, Ciudad Trujillo, R. D., 1939. P. 117.

30.- VEGA, Historia del Derecho Dominicano. P. 344.

31.- WELLES, OP. CIT., Vol. 2. Págs. 265 y 266.

32.- $\quad$ KNIGHT. OP. CIT., 117.

33.- IBID, 122 y 124.

34.- IBID, 118 y 119; WELLES. OP. CIT., Vol. 2. Págs. 265 y 266.

WELLES fue jefe de la División Latino-Americana del Departamento de Estado, y Comisionado del Gobierno de los Estados Unidos en la República Dominicana del 1922 al 1925. Reprobó tales abusos, así escribió: “... queda el hecho cierto de que la política de represión fue desacertada y que su incidencia afectó principalmente a los habitantes pacíficos en quienes, sin que quepa ninguna duda, se cometieron muchas atrocidades". VID SUPRA, Vol. 2, Pág. 265.

35.- Carta del Arzobispo Nouel al Ministro Roussel. 21/V/1920. Boletín Eclesiástico. Nov., 1981. 
36.- WELLES, OP. CIT., Vol. 2, Págs. 265 y 266.

37.- Véase Colección de Ordenes Ejecutivas: Imp. Vda. García, Santo Domingo, R. D., 1918-1923.

38.- MOYA PONS, Frank.- Manual de Historia Dominicana. Universidad Católica Madre y Maestra. Santiago, R. D., 1978. Págs. 493 y 494 .

39.- Véase la Ley de Organización Judicial. Publicaciones de ONAP, Santo Domingo, R. D. 1968.

40.- VEGA, Historia del Derecho Dominicano... 367, 368 y 371.

41.- BALAGUER, Joaquín. La Palabra Encadenada. Fuentes Impresores, S. A., México, 1975. P. 282.

42.- IBID.

43.- IBID.

44.- GALINDEZ, Jesús de.- La Era de Trujillo: Un estudio casuístico de la dictadura hispanoamericana. Editorial Americana, Buenos Aires, 1962. Págs. 162, 166; Cfr GLEIJESES, OP. CIT. 35.

45.- GLEIJESES, OP. CIT. 35.

46.- GALINDEZ, OP. CIT. 142, 143.

47.- En el período 1938-42 hubo renuncias a sólo 16 cargos del Senado. Sólo tres senadores completaron sus mandatos. La Cámara de Diputados, por su parte, tuvo 98 renuncias para 50 curules. Cinco circunscripciones cambiaron de congresistas cuatro veces cada una, y varias otras tres. El 17/VIII/1938, al día siguiente de constituida, aceptó las "renuncias" de 7 diputados, CALINDEZ, OP. CIT, 111-114; GLEIJESES.- OP. CIT., 344, nota 89. 
48.- En su libro Una Gestapo en América (Editora Montalvo, Santo Domingo, R. D. 1968), Jimenes Grullón describe y explica los procedimientos bárbaros y abusivos de la Justicia en la Era de Trujillo contra los opositores. El autor fue uno de los primeros antitrujillistas. Detenido el 19/VII/1934 como sospechoso de intervenir en el complot de Santiago fue indultado el 31 /X/1935. Pasó por el simulacro de un juicio y condenado. Sufrió muchas torturas. Conoció a varios presos políticos que fueron fusilados.

Otros libros de ese carácter son la novela Cementerios sin Cruces, de Andrés Requena, obra que al igual que la de Galíndez le costó su vida; y Complot Desvelado, de Rafael Valera Benítez, en la que describe y narra las salvajes torturas que padecieron él y los demás jóvenes que organizaron el Movimiento Clandestino 14 de Junio, que constituyó la chispa incendiaria de la ira popular contra la tiranía.

49.- GALINDEZ, OP. CIT., 138, 139.

50.- TRUJILLO, Rafael Leónidas.-Discursos, Mensajes y Proclamas. Editorial El Diario, Santiago, 1946-53. (11 Vols). Vol. I, 244, 245.

51.- En un banquete que le ofrecieron los representantes del Poder Judicial, en Santo Domingo, el 18/XI/1933, declaró: "Soy fiel devoto de la independencia del Poder Judicial. Quiero que este Poder no sienta el peso de los otros Poderes". VID SUPRA, I, 391.

52.- $\quad$ El Caribe 24/XI/1954. P. 2.; 25/XI/1954. P. 1, 2.

53.- $\quad$ El Caribe, 11/XI/1954. P. 2.

54.- El robo fue de 149, 268 pesos. Los asaltantes mataron a dos empleados.

55.- $\quad$ El Caribe, 16/XI/1954, P. 1.

56.- CRASSWELlER, Robert D.- La Trágica Aventura del Poder Personal, Editorial Bruguera, S. A., Barcelona, 1968. 2da. edición española. Págs. 430, 431; GLEIJESES.- OP. CIT., 39. 
57.- Los dos únicos sobrevivientes que no fueron apresados fueron Antonio Imbert Barrera y Luis Amiama Tió. Abandonaron sus escondites después de la salida de los Trujillo en noviembre de 1961.

58.- MARTIN, John Bartlow. El Destino Dominicano. Imprime Manuel Pareja, Barcelona, España, 1975. P. 61.

59.- Editorial de New York Times. 12/XII/1961. P. 42.

60.- GLEIJESES, OP. CIT., 77.

61.- Durante su existencia el Tribunal sólo condenó a 4 personas: José Arismendy Trujillo (Petán), Romeo Trujillo Reynoso, Fernando A. Sánchez y Marco Antonio Gómez. Descargó a 37 personas; y en 48 casos no procedió de acuerdo con la ley 48 que declaró confiscados definitivamente los bienes de la familia Trujillo hasta el 4to grado y sus allegados hasta el 3ero. La ley que abolió este Tribunal dispuso que sus atribuciones pasaran a la Corte de Apelación de Santo Domingo. En sentido constitucional la confiscación de bienes la establecen las Constituciones de 10/I/1942 y la del 29/XII/1961. La Constitución del 1963 la abolió en su lugar, estableció la degradación cívica y la devolución de lo hurtado. Sobre este tema véase a Herrera Billini, Hipólito.- La Confiscación General de Bienes y La Nueva Constitución del 29 de Abril del año 1963. El Caribe. 20/IX/1963.

62.- Véase el proceso en VALERA BENITEZ... Complot Desvelado... Págs. 77-135.

63.- GLEIJESES, OP. CIT., Cuadro 3.4 pág. 98.

64.- $\quad$ El Caribe, 7/XI/1963. P. 9.

65.- Pastoral de la Conferencia del Episcopado. Listín Diario, 24/I/1988. P. 14; Mensaje del Presidente Balaguer a la Asamblea Nacional. Listín Diario, 28/11/1988. P. 15. 